\title{
1 Significance of perylene for source allocation of terrigenous organic matter in aquatic sediments
}

4

5 Ulrich M. Hanke ${ }^{1, *}$, Ana L. Lima-Braun ${ }^{1, \ddagger}$, Timothy I. Eglinton ${ }^{1,2}$, Jeffrey P. Donnelly ${ }^{3}$, Valier

6 Galy $^{1}$, Pascale Poussart ${ }^{1, \dagger}$, Konrad Hughen ${ }^{1}$, Ann P. McNichol ${ }^{3}$, Li Xu ${ }^{3}$, Christopher M.

$7 \quad$ Reddy $^{1}$

$8{ }^{1}$ Department of Marine Chemistry and Geochemistry, Woods Hole Oceanographic Institution,

9266 Woods Hole Road, Woods Hole, MA 02543, USA

${ }^{2}$ Geological Institute, ETH Zürich, Sonneggstrasse 5, 8092 Zurich, Switzerland

${ }^{3}$ Department of Geology and Geophysics, Woods Hole Oceanographic Institution, 266 Woods Hole Road, Woods Hole, MA 02543, USA

$\star$ Current address: ExxonMobil Exploration Company, Spring, Texas, USA

${ }^{\dagger}$ Current address: Princeton University, 36 University Place, Princeton, New Jersey 08544 USA

*corresponding author: uhanke@,whoi.edu
ABSTRACT
Perylene is a frequently abundant, and sometimes the only polycyclic aromatic hydrocarbon $(\mathrm{PAH})$ in aquatic sediments, but its origin has been subject of a longstanding debate in geochemical research and pollutant forensics because its historical record differs markedly from typical anthropogenic PAHs. Here we investigate whether perylene serves as a source-specific molecular marker of fungal activity in forest soils. We use a well-characterized sedimentary 
record (1735 to 1999) from the anoxic-bottom waters of the Pettaquamscutt River basin, RI,

31 USA to examine mass accumulation rates and isotope records of perylene, and compare them

32 with total organic carbon and the anthropogenic PAH fluoranthene. We support our arguments

33 with radiocarbon $\left({ }^{14} \mathrm{C}\right)$ data of higher plant leaf-wax $n$-alkanoic acids. Isotope-mass balance-

34 calculations of perylene and $n$-alkanoic acids indicate that $40 \%$ of sedimentary organic matter

35 is of terrestrial origin. Further, both terrestrial markers are pre-aged on millennial time-scales

36 prior to burial in sediments and insensitive to elevated ${ }^{14} \mathrm{C}$ concentrations following nuclear

37 weapons testing in the mid- $20^{\text {th }}$ Century. Instead, changes coincide with enhanced erosional

38 flux during urban sprawl. These findings suggest that perylene is definitely a product of soil-

39 derived fungi, and a powerful chemical tracer to study spatial and temporal connectivity

40 between terrestrial and aquatic environments.

41

42

43

44

45

\section{INTRODUCTION}

Perylene is found in marine ${ }^{1-5}$ and lacustrine sediments ${ }^{6-8}$, in soils ${ }^{9,10}$, and also in petroleum 11,12 and fuel emissions ${ }^{13,14}$ often associated with other distinctive anthropogenic combustionderived polycyclic aromatic hydrocarbons (PAHs). However, most studies report that sediment records of perylene differ greatly from those of anthropogenic PAHs ${ }^{15-19}$. The latter are typically most abundant in sediments post-dating the Industrial Revolution, particularly those deposited during the latter half of the $20^{\text {th }}$ Century, whereas perylene abundances are lowest near the sediment-water interface and tend to increase with depth, particularly in anoxic sedimentary settings ${ }^{18,20}$. This depth-related increase in concentration implies abiotic or biologically mediated in situ production from precursor natural product(s) ${ }^{2,21}$ by either a firstor second-order reaction under anaerobic conditions ${ }^{20}$. 
56 The origin of perylene has remained unclear for decades, during which has previously been 57 argued for terrestrial ${ }^{1,2,22,23}$ and diagenetic ${ }^{6,16,24}$, as well as petrogenic ${ }^{12,25}$ and pyrogenic ${ }^{13,14}$ 58 sources. It was only recently that Itoh and collaborators ${ }^{23}$ determined that the fungal species Cenococcum geophillum produces 4,9-dihydroxyperylene-3,10-quinone, confirming a

60 longstanding hypothesis ${ }^{1,22}$ that there is a naturally produced precursor. This ectomycorrhizal 61 fungus appears almost ubiquitous in boreal, temperate and subtropical regions, and present in 62 the rhizosphere of woody-plant roots and more generally in forest soils ${ }^{26}$. A fungal origin can 63 explain the widespread abundance of perylene in the environment even over geological timescales $^{27}$, since mycorrhizal associations with vascular plants evolved about 400 million years ago ${ }^{28}$.

66

67 Besides C. geophyllum, other mycorrhiza also produce similar perylene precursor compounds ${ }^{29,30}$ as toxins involved in pathogenesis of their host plant ${ }^{31}$. Prior stable carbon isotopic $\left(\delta^{13} \mathrm{C}\right)$ measurements of perylene found values similar to those terrestrial sources $\left(\mathrm{C}_{3}\right.$-vegetation: $\delta^{13} \mathrm{C}$ $\approx-27 \%$ ), supporting a wood-degrading origin from the rhizosphere ${ }^{32}$. This is further supported by dual-isotope analyses of perylene $\left(\delta^{13} \mathrm{C}\right.$ and $\left.\delta \mathrm{D}\right)$ in sediments showing similar $\delta \mathrm{D}$ values as methoxy groups in lignin while $\delta^{13} \mathrm{C}$ values are consistent with the expected fractionation range in saprophytic fungi ${ }^{22}$. In addition, natural abundance radiocarbon $\left({ }^{14} \mathrm{C}\right)$ analyses allows a comparison of the ${ }^{14} \mathrm{C}$ age of perylene with that of other organic matter constituents $^{25}$, including total organic carbon (TOC) and specific markers of terrigenous organic matter co-deposited in aquatic sediments. Such analyses shed light on the origin and provide further evidence on the origin of perylene and its use in environmental forensics. 
79 Our motivation is to reconcile existing hypotheses on the source of perylene and assess the 80 potential of this marker compound as a biogeochemical tracer to follow the trajectories of 81 terrigenous organic matter mobilization and transport within watersheds. Specifically, we 82 investigate whether it serves as a molecular marker for rhizosphere carbon from catchment soils 83 and thus facilitates source approximation of terrigenous organic matter in sediments. Moreover, 84 while researchers currently tend to exclude perylene from forensic investigations involving the 85 apportionment of PAHs due to its incongruent behaviour, perylene may have mutagenic effects on organisms ${ }^{33,34}$. Thus, an improved understanding of the provenance and dynamics of

87 perylene may be pertinent to mapping inventories of natural and anthropogenic pollutants, 88 delineating transport pathways, and reconstructing historical land-use.

In this study, we construct historical records of perylene and TOC abundances and isotope compositions from the anoxic sediments of the suburban Pettaquamscutt River basin, RI, USA.

92 We chose these sediments because they provide an exceptionally detailed chronological record 93 and a wealth of background information on the catchment area, including human influence on 94 local to regional scales ${ }^{15,35-38}$. In addition, this sedimentary record extends over 260 years, 95 from the pre-industrial ( 1735) until 1999, including an interval characterized by frequent above-ground nuclear-bomb testing (resulting in elevated atmospheric ${ }^{14} \mathrm{C}$ concentrations

97 peaking in 1963 when the testing ceased), thus offering the opportunity to study the rate at which specific organic carbon species incorporate atmospheric $\mathrm{CO}_{2}$ and are sequestered in 99 aquatic sediments. These characteristics of the study site, when coupled with down-core $\delta^{13} \mathrm{C}$ and ${ }^{14} \mathrm{C}$ records, provide a novel perspective on perylene biogeochemistry, yielding constraints

101 on its source and on the burial efficiency of terrigenous organic matter in aquatic sediments.

102 We compare mass accumulation rates (MAR) of perylene and TOC to the combustion-derived 
103 PAH marker fluoranthene. While several non-alkylated PAHs could be used to trace past-

104 combustion practices, we choose fluoranthene because its quantitative down-core profile

105 resembles the temporal evolution of the sum of 15 parent PAHs in this watershed ${ }^{15}$. We further

106 support our interpretation with down-core data of particle size and leaf wax $\left(\mathrm{C}_{30-32} ; n\right.$-alkanoic

107 acids ${ }^{14} \mathrm{C}$ variations. We then carefully assess whether the rhizosphere of wooded land serves

108 as the direct source for perylene in the environment and discuss the process of pre-ageing of

109 terrestrial organic matter prior to delivery into the aquatic environment in the context of parallel

110 sedimentary records.

111

\section{EXPERIMENTAL SECTION}

113 A series of seven freeze cores were collected in the depocenter of the lower basin of the

114 Pettaquamscutt River basin, RI, USA (41.503100; -71.450500) in 1999. The catchment area

115 covers $35 \mathrm{~km}^{2}$ of forest, wetlands and open water of which today about $30 \%$ is residential land

$116{ }^{37}$. Ocean water flooded the basin about $1700 \pm 300$ years ago leading to a stratified water

117 column and sustained anoxic conditions in bottom waters and underlying sediments ${ }^{36}$. A

118 detailed description on the sediment chronology and sample processing is presented elsewhere

11915,39 . Sediment chronology was obtained from varve counting of $\mathrm{x}$-ray radiographs as well as

120 from ${ }^{137} \mathrm{Cs}$ and ${ }^{210} \mathrm{~Pb}$ profiles using the model of constant rate of supply that yielded a sequence

121 of about 260 years (1735-1999 AD) and an average sedimentation rate of $0.44 \pm 0.10 \mathrm{~cm} \mathrm{yr}^{-1} 39$.

123 Sections from the cores were combined after aligning x-radiograph images including hurricane

124 layers in 1938 and 1954 to a reference chronology of varve counting, ${ }^{210} \mathrm{~Pb}$, and ${ }^{137} \mathrm{Cs}$. This was 125 necessary to obtain enough sediment for trace molecular isotopic-analyses ${ }^{35}$. Hence, we pooled 
126 the samples in eight horizons for all isotopic analyses: H1 (1999-1982), H2 (1981-1962), H3

127 (1960-1931), H4 (1929-1898), and H5 (1896-1873), H6 (1871-1842), H7 (1840-1768), and

128 H8 (1764-1735) respectively, except $n$-alkanoic acids that were analyzed in four individual

129 samples: $1885 \pm 5,1947 \pm 33,1972 \pm 2$, and $1991 \pm 1$. Quantitative measurements for the

130 calculation of the mass accumulation rates as well as grain size analyses were performed on

131 individual samples as well.

132

133 Grain size analyses

134 One freeze-core slab was sub-sectioned using a scalpel blade, transferred into 50-mL round

135 bottom flasks and treated with a $30 \%$ hydrogen peroxide solution at a ratio of $40 \mathrm{ml}$ per $1 \mathrm{~g}$

136 sediment, and heated in a water bath to $70{ }^{\circ} \mathrm{C}$ as a means to support mineralization of the

137 organic matter. Subsequently, samples were freeze dried, and a subsample of about $11 \mathrm{mg}$ was

138 suspended in water and measured on a Beckmann Coulter LS13 320 Laser Diffraction Particle

139 Analyser (Indianapolis, USA) in triplicate.

140

141 Total Organic Carbon and Nitrogen

142 A Fisons 1108 elemental analyzer was used to measure the TOC content of the samples. To

143 remove the inorganic carbon fraction, about $2 \mathrm{mg}$ of dry sample was weighed into a silver

144 capsule and acidified with $20 \mu \mathrm{L}$ of $2 \mathrm{~N} \mathrm{HCl}$. TOC content was calculated in relation to the

145 whole sediment dry weight while organic carbon/organic nitrogen TOC/TN ratios were

146 calculated on an atomic basis. Samples were run in triplicate and all reported weight

147 percentages represent the mean \pm one standard deviation with an instrumental blank of 0.004

$148 \mathrm{mg}$ for $\mathrm{C}$ and smaller than $0.005 \mathrm{mg}$ for $\mathrm{N}$.

149 
151 The stable carbon isotopic composition of bulk sample TOC was determined in triplicate by

152 automated on-line solid combustion interfaced to a Finnigan Delta Plus isotope ratio mass

153 spectrometer. Isotope ratios were calculated relative to $\mathrm{CO}_{2}$ reference gas pulses, with standard

154 deviations for replicate measurements were always better than $0.6 \%$ and usually within $0.3 \%$.

155

156 Extraction, purification and isotope analyses of perylene, fluoranthene and $\boldsymbol{n}$-alkanoic

157 acids

158 Dry sediment samples (0.5-1.5 g) were extracted by pressurized fluid extraction (Dionex ASE

159 200) using a mixture of acetone and $n$-hexane (1:1) at 1000 psi at $100{ }^{\circ} \mathrm{C}$. Molecular

160 identification and quantification was achieved using an Agilent 6890 Plus GC System

161 interfaced to a mass selective detector operating at $70 \mathrm{eV}$ in SIM mode using a DB-XLB

162 capillary column $(60 \mathrm{~m} \times 0.25 \mathrm{~mm} \times 0.25 \mu \mathrm{m})^{15}$.

163

164 Compound-specific radiocarbon analyses (CSRA) of perylene and fluoranthene were performed

165 on eight pooled horizons by first using high-pressure liquid-chromatography (HPLC) to

166 separate pure perylene (98\% purity or greater) from the sample extracts. The HPLC procedure

167 isolated PAHs into 2-ring and the combined 3+4-ring and 5+6-ring PAHs. The resulting 16

168 HPLC fractions (8 horizons $\mathrm{x} 2$ ring classes) were subjected to two-dimensional preparative

169 capillary gas chromatography for isolation and purification of individual PAHs via HP 7683

170 auto-injector and a multi-column switching system (Gerstel MCS 2) connected to a HP 6890

171 series gas chromatograph, and Gerstel preparative fraction collector (PFC; further details in SI).

172 Purified samples were transferred to pre-combusted quartz tubes ( $7 \mathrm{~mm}$ I.D. $\times 20 \mathrm{~cm})$, dried

173 under nitrogen before adding copper oxide $(50 \mathrm{mg})$. Each tube was then evacuated on a vacuum 
174 line while samples were kept at $-90^{\circ} \mathrm{C}$ to prevent sublimation, sealed, and combusted at $850^{\circ} \mathrm{C}$

175 for five hours. About $95 \%$ of the purified carbon dioxide was reduced to graphite, pressed and

176 analyzed for ${ }^{14} \mathrm{C}$ at NOSAMS, Woods Hole, U.S. and the remaining $5 \%$ was used for $\delta^{13} \mathrm{C}$

177 measurements.

178

179 The $\delta^{13} \mathrm{C}$ values of perylene were determined in triplicate on a Finnigan Delta Plus isotope ratio 180 mass spectrometer with attached Finnigan GC combustion III interface and Hewlett-Packard 181 6890 GC (irm-GC/MS). Compounds were separated on a CP-Sil 5CB capillary column (50 m $\times$

$1820.25 \mathrm{~mm} \times 0.25 \mu \mathrm{m})$ and isotope ratios for PAH peaks were calculated relative to $\mathrm{CO}_{2}$

183 reference gas pulses. The standard deviation for replicate measurements of perylene was better

184 than $0.6 \%$ and mostly around $0.2 \%$.

186 The isotopic composition of leaf wax $n$-alkanoic acids $\left(\mathrm{C}_{30-32}\right)$ were determined for four 187 individual sediment samples deposited in $1885 \pm 5,1947 \pm 33,1972 \pm 2$, and $1991 \pm 1$ following the analytical procedure described elsewhere ${ }^{40}$. In brief, $n$-alkanoic acids were extracted, isolated, and purified using a preparative Hewlett Packard 5890 series II capillary gas chromatograph ${ }^{41}$. Following the chromatographic purification of individual compounds, samples were graphitized and measured at NOSAMS, Woods Hole, U.S.

192

\section{Evaluation of isotope data}

194 Isotope mass-balance calculations provide quantitative estimates for source apportionment of

195 organic matter. To constrain the sources of TOC and perylene in Pettaquamscutt River

196 sediments, we calculated the relative contribution of possible organic carbon sources in the

197 sediments using the measured ${ }^{14} \mathrm{C}$ and $\delta^{13} \mathrm{C}$ values for TOC (Figure 2). We report the ${ }^{14} \mathrm{C}$ data 
as $\mathrm{F}^{14} \mathrm{C}$ which is the fraction modern independent from the year of measurement ${ }^{42}$. We assumed a simple mixing model to retrieve an average value for the lag-time of perylene and leaf wax $n$-alkanoic acids; the details of which are published elsewhere ${ }^{35}$. In brief, these source-specific molecular markers facilitate approximations of the contributions of terrigenous organic matter in aquatic sediments (further details on the concept are included in SI).

To account for the potential variability under increasing human pressure on the coastal

environment, we determined average values of our terrestrial end-members for two time periods: the pre-industrial (1735 to 1840) and the post-'bomb' (1960 to 1999) period (see SI for more detail). Regarding ${ }^{14} \mathrm{C}$ data evaluation, the post-1960s period also is a benchmark to test

207 for the resilience and short-term dynamics of catchment processes. In contrast, the aquatic endmember is only affected by the marine reservoir effect, which is about $400 \pm 40{ }^{14} \mathrm{C}$ years lower than the atmospheric ${ }^{14} \mathrm{C}$ concentration at the time of burial ${ }^{43}$. Furthermore, we neglect a potential impact of petrogenic carbon ${ }^{44}$ in the Pettaquamscutt River because of the absence of

211 post-glacial erosion and due to the absence of carbonaceous metasedimentary rocks in the basin

$212{ }^{45}$. We constrain our model by $\delta^{13} \mathrm{C}=-21.0 \%$ for aquatic production ${ }^{46}$ and use local records of 213 perylene, pyrogenic carbon ${ }^{35}$ and $n$-alkanoic acids $\left(\mathrm{C}_{30-32}\right)$ to define terrestrial end-members.

214 We further obtained the contemporary atmospheric ${ }^{14} \mathrm{C}$ concentrations from the extended 215 Intcal13 reference chronology $43,47$.

\section{RESULTS AND DISCUSSION}

218 The exceptionally well-constrained chronology of the Pettaquamscutt River sediments along with detailed reconstructions of the provenance of combustion-derived PAHs ${ }^{15,35}$ and $\mathrm{Hg}^{38}$

220 provide key constraints that allow us to determine whether perylene signatures are consistent 221 with its production in the rhizosphere of catchment soils ${ }^{23,26}$. To characterize the export of 
terrigenous organic matter, including the putative precursors of perylene, and its subsequent

223 burial in aquatic sediments, we report MAR for TOC, perylene, and fluoranthene. Isotopic mass

224 balance calculations for $\delta^{13} \mathrm{C}$ and ${ }^{14} \mathrm{C}$ records are employed to further constrain the main source

225 of perylene precursors. With reference to recent research and our results, we then provide a 226 synthesis aiming to merge the existing concepts, reconciling the origin of perylene (i.e., 227 terrestrial, diagenetic or petro-/pyrogenic).

228

\section{Down-core mass accumulation rates of TOC and perylene}

230 The burial rate of TOC in the sediments of the Pettaquamscutt River ranges from 38 to $61 \mathrm{~g} \mathrm{~m}^{-2}$

$231 \mathrm{yr}^{-1}\left(\right.$ average $\left.=49 \pm 6 \mathrm{~g} \mathrm{~m}^{-2} \mathrm{yr}^{-1}, n=71\right)$. The lowest TOC burial flux is observed in ca. 1938

232 (Figure 1) and is related to a $16.7 \%$ shift in burial flux from $53.0 \pm 43 \mathrm{~g} \mathrm{~m}^{-2} \mathrm{yr}^{-1}$ prior to ca.

2331927 to $44.0 \pm 3.7 \mathrm{~g} \mathrm{~m}^{-2} \mathrm{yr}^{-1}$ for sediments deposited thereafter. The timing of this change

234 coincides with the construction of the Lacey Bridge on the ocean side of the lower basin in $23519344^{45}$ (Figure 1B) that likely caused a restriction in seawater intrusion, affecting the influx of

236 both marine as well as the terrestrial matter. We argue that this exemplifies the accelerated

237 development of the catchment area beginning early in the last century and the related

238 infrastructure projects that changed the natural flow paths of materials within the watershed.

240 The $\mathrm{N}_{\text {org }}$ down-core record reveals only small variations, here illustrated as $\mathrm{C}_{\text {org }} / \mathrm{N}_{\text {org }}$ profiles (n

$241=71$; Figure 1) where three trends are delineated: decreasing $\mathrm{C} / \mathrm{N}$ from $1730 \mathrm{~s}$ (12.6) to $1840 \mathrm{~s}$

242 (9.4), a 50-year reversal towards higher $\mathrm{C} / \mathrm{N}$ ratios (13.2 in 1900), and a century-long $\mathrm{C} / \mathrm{N}$

243 secular decrease in the upper core (10.0 in 1999). This rather narrow range in $\mathrm{C} / \mathrm{N}$ ratios

244 suggests that organic matter is predominantly yet not exclusively composed of labile material

245 with $\mathrm{C} / \mathrm{N}$ values similar to aquatic organic matter $(\mathrm{C} / \mathrm{N}=4$ to 10$){ }^{48}$. However, we refrain from 
246 further speculations on this bulk-level information due to the absence of a robust reference for $247 \mathrm{C} / \mathrm{N}$ values of terrigenous organic matter from this area.

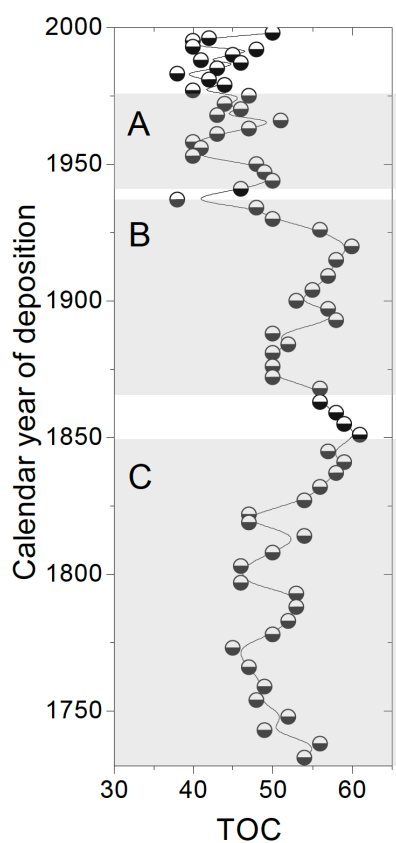

$\left[\mathrm{g} \mathrm{m}^{-2} \mathrm{yr}^{-1}\right]$

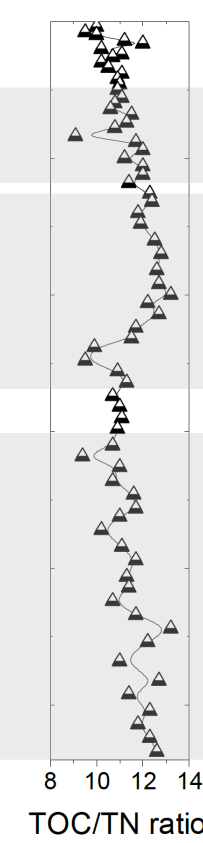

$[-]$

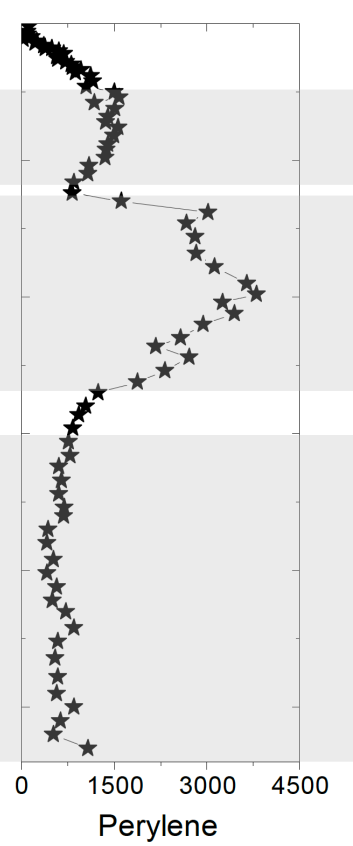

$\left[\mu \mathrm{m} \mathrm{m}^{-2} \mathrm{yr}^{-1}\right.$ ]

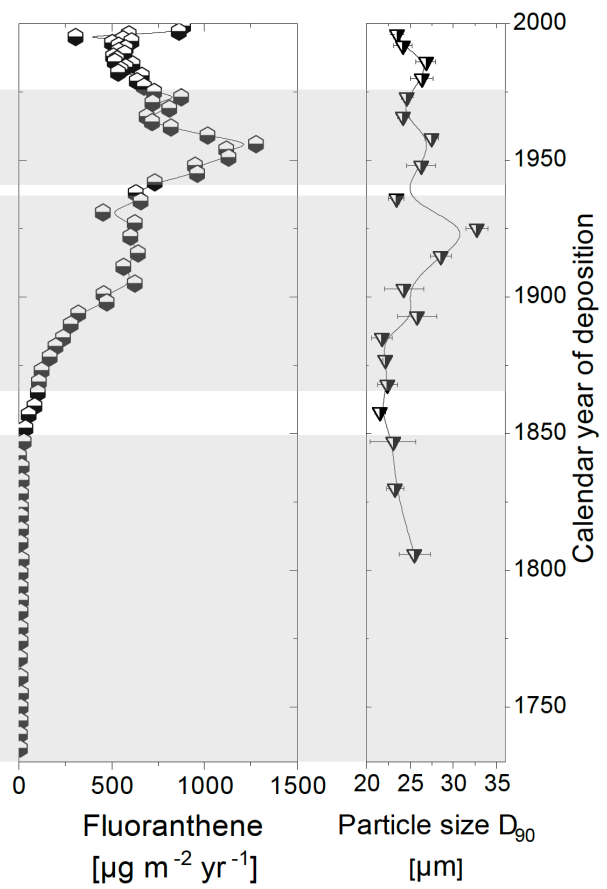

$[\mu \mathrm{m}]$

250 Figure 1: Mass accumulation rates for total organic carbon (TOC), perylene, and fluoranthene as well as carbon to nitrogen

251 (TOC/TN) ratios and down-core shifts in coarse particle abundance $\left(\mathrm{D}_{90}\right)$ with shaded area $\mathbf{A}$ representing the maximum PAH

252 flux in this area, B the period of amplified erosion due to infrastructure development, and $\mathbf{C}$ the pre-industrial era prior to 2531840 s.

255 MARs for perylene/proto-perylene, which corresponds to the reduced perylene quinone, vary 256 from 29 to $3800 \mu \mathrm{g} \mathrm{m}^{-2} \mathrm{yr}^{-1}$, while its down-core profile differs markedly from the combustion257 marker fluoranthene (Figure 1). The values were low before 1938, reached a maximum between ca. 1938 and $1973\left(1580 \mu \mathrm{g} \mathrm{m}^{-2} \mathrm{yr}^{-1}\right)$, before diminishing again in most recent decades $(\sim 100$ $\left.\mu \mathrm{g} \mathrm{m}^{-2} \mathrm{yr}^{-1}\right)$ (Figure 1). This contrasting accumulation behaviour implies a different origin for perylene relative to combustion-derived PAHs, here illustrated by fluoranthene (Figure 1). This non-alkylated PAH appears lower in abundance varying from 1 to $1280 \mu \mathrm{g} \mathrm{m}^{-2} \mathrm{yr}^{-1}$ and also 
262 exhibits significant variability ${ }^{35}$, however the temporal evolution of MARs of this pyrogenic 263 PAH differs sharply with that of perylene. Specifically, fluoranthene's MAR was low until the 264 mid-19 $19^{\text {th }}$ century (Figure 1C), increased steadily to a maximum in the late-1950s, then declined 265 in the post-1970s due to cleaner burning fuels and as consequence of environmental regulations $266{ }^{15,37}$. Such down-core profiles of combustion-derived PAHs are also observed in other 267 sedimentary records, including the upper basin of the Pettaquamscutt River ${ }^{16,19,49}$.

269 The observed decline in perylene/proto-perylene MAR between 1927-1938 coincides with the 270 abrupt decrease in TOC accumulation rate (Figure 1B). We attribute the latter to a dilution in 271 organic carbon content resulting from a higher proportion of clastic material due to erosion of 272 soil mineral horizons (Figure 1). Perylene is a trace constituent of TOC, never accounting for 273 more than $0.1 \%$ of TOC, and consequently perylene/TOC ratios shift by $500 \%$ relative to 274 before or after this time interval. These observations thus support the link between a decrease in 275 perylene's MAR resulting from an increase in erosional flux (Figure 1B).

276

277 A striking feature of the perylene profile is that fluxes remain nearly constant $\left(665 \pm 180 \mu \mathrm{g} \mathrm{m}^{-2}\right.$ $\left.278 \mathrm{yr}^{-1} ; \mathrm{n}=26\right)$ prior to 1865 , indicating either steady-state erosional conditions or quantitative 279 conversion of precursor material (Figure 1) ${ }^{23}$. Due to the large variations in perylene burial 280 rates in our sedimentary record we refrain from attempting to derive kinetic parameters for 281 conversion of perylenequinone (proto-perylene) precursor to perylene. However, Slater and 282 collaborators ${ }^{50}$ compared two perylene profiles from Lake Siskiwit collected in 1983 and 2005. 283 They found a reaction rate constant $\left(0.048 \mathrm{yr}^{-1}\right)$, ca. $75 \%$ higher than previously reported 20 284 while another study reported much lower rates ${ }^{18}$. All of the above studies suggest that the 285 conversion of perylenequinone to perylene follows first-order kinetics. Nevertheless, the strong 
( 97\%) decrease in perylene abundance in Pettaquamscutt River sediments from 1973 to 1999

287 likely reflects incomplete conversion of precursor compounds (Figure 1).

\section{Isotope mass balance calculations}

290 The $\delta^{13} \mathrm{C}$ TOC profile (Figure 2) appears relatively invariant throughout the core (-25.4 to -23.0

$291 \%$, average $-24.1 \pm 0.5 \%, n=36$ ), indicating the absence of large variations in organic matter composition. Although the TOC MAR decreased in the $1930 \mathrm{~s}, \delta^{13} \mathrm{C}$ values do not suggest this

293 was accompanied by a shift in the nature of organic matter supplied to Pettaquamscutt River

294 basin. Instead, the observed changes in burial flux in this catchment are attributed to a shift in

295 land use stemming from an increase in the local human population and the accompanied

296 development of infrastructure. The $\delta^{13} \mathrm{C}$ values of perylene (-28.9 to $-28.3 \%$; average $-28.6 \pm$

$2970.6 \%$; Figure 2) were similarly invariant, while significantly lower than TOC and similar to

298 that reported for terrestrial $\mathrm{C}_{3}$ plants (-29 to -25 , average $-28 \%$ o) ${ }^{51}$.
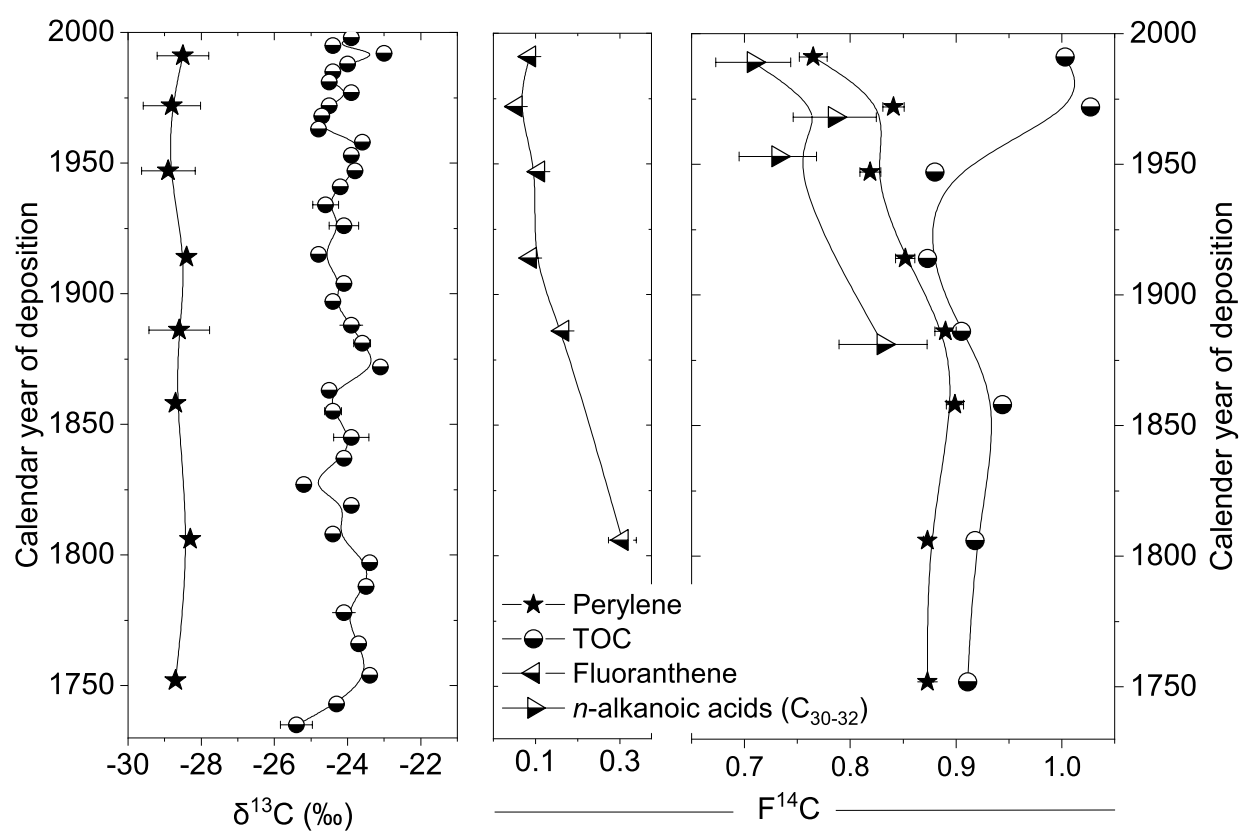

Figure 2: High-resolution $\delta^{13} \mathrm{C}$ record for TOC and pooled sample results for perylene (left); molecular ${ }^{14} \mathrm{C}$ data for the 
301 In contrast, the ${ }^{14} \mathrm{C}$ record of TOC for pooled samples $(n=8$; Figure 2$)$ reveals only small

302 variations in pre-industrial time (1735 to 1840$)$ but then tends to shift towards more ${ }^{14} \mathrm{C}$

303 depleted values between 1839 and 1958. This change is thought to integrate the increasing use

304 of fossil fuels slightly diluting the natural atmospheric ${ }^{14} \mathrm{C}$ concentration (the so-called 'Suess

305 effect') as well as on-going infrastructural development and constructions within the catchment

306 resulting in the mobilization of deeper mineral soils. Thereafter, we observed a drastic $(\sim 15 \%)$

307 increase in $\mathrm{F}^{14} \mathrm{C}$ TOC values reflecting the shift in atmospheric ${ }^{14} \mathrm{C}$ derived from thermonuclear

308 weapons testing in the post-1960s. The uppermost sediment layer signals declining ${ }^{14} \mathrm{C}$

309 concentrations similar to the atmosphere ${ }^{47}$.

310

311 Compound-specific radiocarbon analysis reveals that the ${ }^{14} \mathrm{C}$ profile of perylene follows that of

312 TOC from the pre-industrial period until $\sim 1950$. Thereafter, ${ }^{14} \mathrm{C}$ of TOC increases due to the

313 incorporation of atmospheric bomb ${ }^{14} \mathrm{C}$, while perylene trends to more ${ }^{14} \mathrm{C}$-depleted values.

314 This could reflect a pyrogenic (fossil fuel) contribution to perylene, mitigating the impact of

315 'bomb' carbon in the Pettaquamscutt River sediments. However, CSRA of leaf wax $n$-alkanoic

316 acids $\left(\mathrm{C}_{30-32}\right)$ from the same sediments reveals a concomitant ${ }^{14} \mathrm{C}$ trend with perylene (Figure

317 2). We infer, therefore, that leaf waxes and perylene share a common source and mode of

318 export, implying that local erosional fluxes and mobilization of soil organic matter are

319 responsible for the decoupled TOC and perylene post-1950s signals rather than global-scale

320 perturbations such as 'Suess effect' or above-ground nuclear weapons testing.

322 In the mainly wooded catchment area of Pettaquamscutt River, organic molecules are produced

323 during photosynthetic activity, translocated and metabolized in plants, as well as released into

324 the rhizosphere. In the soil, plant and animal residues can be assimilated, stabilized and 
metabolized until they eventually become respired to carbon dioxide ${ }^{52}$, or they can be eroded

326 and redistributed within the watershed ${ }^{53}$. Source-specific molecular markers allow delineation

327 of specific processes associated with organic matter cycling, while molecular ${ }^{14} \mathrm{C}$ data provide

328 additional information on the timescales of organic matter storage and transport from its source

329 to the "ultimate' site of burial. This "residence time" has been determined for several markers

330 of terrestrial primary productivity ${ }^{54-56}$, as well as charred plant biomass ${ }^{35,57}$, and range from

331 centuries to several millennia. The underlying processes resulting in organic matter 'pre-aging'

332 prior to burial in aquatic depocenters can complicate source apportionment because the ${ }^{14} \mathrm{C}$

333 concentration of various organic matter components differs from that of the corresponding

334 atmospheric ${ }^{14} \mathrm{C}$ reference value.

335

336 We determined an average ${ }^{14} \mathrm{C}$ residence time for perylene of $1300 \pm 300{ }^{14} \mathrm{C}$ years for samples

337 pre-dating the industrialization $(1735-1840, \mathrm{n}=3)$ and $2000 \pm 500{ }^{14} \mathrm{C}$ years for the post-

338 'bomb' era $(1960-1999 ; \mathrm{n}=3)$. These values agree well with leaf wax $n$-alkanoic acids $\left(\mathrm{C}_{30-32}\right)$

339 that showed a $2700 \pm 700{ }^{14} \mathrm{C}$ year residence time for the post-'bomb’ era (Figure 2), and a

340 record of biomass-derived pyrogenic carbon from the same core revealed an average age of

$341 \quad 1460 \pm 490{ }^{14} \mathrm{C}$ years for the pre-industrial era ${ }^{35}$. The apparent average age or residence time

342 over the pre-industrial and the post-'bomb' era for perylene and higher plant $n$-alkanoic acids of

343 ca. $2000{ }^{14} \mathrm{C}$ years is slightly higher than has been reported for (micro) charcoal in the same

344 catchment ${ }^{35}$ as well as for leaf wax $n$-alkanoic acids in the Bengal fan ${ }^{55}$ yet similar to that of

345 Cariaco basin ${ }^{56}$. However in the post-'bomb' era we observed a decoupling of ${ }^{14} \mathrm{C}$

346 concentrations among molecular markers and TOC. Specifically, the increase in atmospheric

$347{ }^{14} \mathrm{C}$ concentrations post-1960s is not apparent in perylene or $n$-alkanoic acids, suggesting that

348 soil carbon storage on millennial timescales may conceal or delay the legacy. 
350 Isotope mass balance calculations based on TOC ${ }^{13} \mathrm{C}$ and ${ }^{14} \mathrm{C}$ data yield similar values for the 351 proportion of organic matter of terrestrial origin $\left(\delta^{13} \mathrm{C}:-43 \pm 10 \%\right.$ and $\left.{ }^{14} \mathrm{C}:-37 \pm 10 \%\right)$, with 352 the remaining carbon derived from aquatic productivity. These results for the Pettaquamscutt

353 River basin are slightly higher than an estimated global average of one-third of sedimentary

354 organic of terrestrial origin ${ }^{58}$. The similar estimates obtained from dual-carbon isotope 355 evaluations based on perylene reinforce its value in constraining the terrestrial end-member in 356 source apportionment.

\section{New constraints on the source of perylene}

359 The origin and widespread distribution of perylene in the environment has been a subject of 360 scientific debate for decades, although its conversion from the precursor molecule, 4,9-

361 dihydroxyperylene-3,10-quinone, has long been suspected ${ }^{1,2,23,29}$. In particular, it has remained 362 unclear whether perylene is formed during in-situ diagenesis ${ }^{6,16}$ or is of petro-/pyrogenic origin 363 $11,14,25,59$. The former hypothesis was stimulated by the presence of perylene in Antarctic marine 364 sediments ${ }^{60}$ and by large similarities between perylene and total organic matter down-core 365 profiles, fueling the notion of in-situ synthesis from TOC ${ }^{16}$. Along these lines, Gschwend and 366 collaborators ${ }^{20}$ calculated kinetic parameters necessary to yield perylene from biogenic 367 precursor concentrations that are consistent with results from a recent study comparing down368 core profiles 20 years apart in Lake Siskiwit ${ }^{50}$, and both are in line with the observed reduction 369 of perylenequinones ${ }^{23}$. The second alternative hypothesis is based on the abundance of perylene in ancient sediments ${ }^{22,61}$, fossil fuels ${ }^{11,12}$ or combustion emissions ${ }^{13,14,59}$. Regarding

371 the latter sources, perylene concentrations remain below $1.4 \%$ of the total PAH and thus are 372 negligible for the overall budget. Its presence in these matrices, however, raises the question of 
whether perylene is exclusively of fungal origin. A possible explanation for the occurrence of perylene in fossil fuels lies in the evolutionary development of fungi. The symbiotic interaction between fungi and vascular plants evolved about $400 \mathrm{Ma}$ ago, and ectomycorrhiza have existed for at least $56 \mathrm{Ma}^{62}$, while the divergence and evolution of the mycorrhiza gene pool remains largely unexplored ${ }^{28}$. However, Blumer proposed the conversion of pigments to hydrocarbons through a geochemically irreversible deoxygenation of functional groups and hydrogenation under sustained reducing conditions ${ }^{63}$. Even though this was exemplified for fossil crinoids in a pigment-rich Triassic oil shale, these reactions likely also apply to the precursors of biogenic PAH. We deduce, therefore, that fungal-derived perylenequinone is deoxygenated during sediment diagenesis and, at least partly, survives coalification. This could explain the occurrence of perylene in fossil deposits ${ }^{32}$ and could explain its abundance in combustion residues. One evolutionary rationale for the occurrence of perylene in scletoria, the resting structures of C. geophyllum ${ }^{64}$, is the extreme mutagenic activity of the unsaturated nucleus of perylenequinones on gram-negative bacteria ${ }^{33}$, protecting the reproductive function of fungal spores. Overall, the preponderance of evidence ${ }^{17,22,32}$, reinforced by our new data, indicates that perylene is a remnant of wood degradation or fungal activity in the rhizosphere - a hotspot of biological activity on land, and source of organic matter to aquatic systems.

\section{Parallels between perylene and TOC}

Sedimentary organic matter is a highly complex mixture composed of aquatic and terrigenous organic carbon, and this complexity complicates source apportionment calculations, as well as determination of carbon fluxes and thus the carbon burial efficiencies ${ }^{65,66}$. Measurement of the abundance and isotopic composition of source-specific molecular markers can provide constraints on terrigenous organic matter in sediments ${ }^{65}$. In addition to source constraints from 
$397 \quad \delta^{13} \mathrm{C}$ and ${ }^{14} \mathrm{C}$ signatures, the latter also yields information on whether organic matter is of 398 modern or fossil origin ${ }^{44}$, as well as on timescales of terrigenous organic matter between 399 formation on land and burial in aquatic depocenters (i.e., "average residence times") ${ }^{35}$. The 400 process of 'pre-aging' implies a lag between biosynthesis and export of organic matter from

401 land to depocenter, with natural as well as anthropogenic molecules being retained in catchment 402 soils from annual to millennial time-scales $35,55,56$. Here, we find that this pre-aging process 403 occurs on similar time-scales for leaf wax fatty acids ( $n$-alkanoic acids), biomass-derived 404 pyrogenic carbon and the rhizosphere tracer perylene - all together terrestrial markers with different modes of formation, chemical structures and functionalities. This agreement between these different source-specific markers suggests that retention within soils regulates the export of most terrigenous organic matter and associated carbon-based pollutants that enter the soil 408 column.

TOC and perylene MARs co-vary in the pre-industrial era until about 1850 despite some 411 variability in the TOC flux (Figure 1). We attribute the latter to the increasing pressure by 412 extensive farming, as well as potential changes in aquatic productivity. The dual carbon isotope 413 records for TOC and perylene (Figure 2) support the absence of drastic compositional shifts 414 throughout the record, despite the influence of the 'Suess effect' and nuclear weapons testing 415 on the latter part of the TOC ${ }^{14} \mathrm{C}$ record. Notably, perylene shows large variation in MAR after 1850 , which we suspect is due to the conversion of the catchment from a rural into a sub-urban landscape that was accompanied by an enhanced erosional flux of carbon from bare soils. these cases it was suspected to reflect direct in-situ microbial production of perylene ${ }^{16}$ rather 
421 than the reduction and conversion of a precursor into perylene. This depletion of the precursor

422 pool may continue over geological time scales ${ }^{63}$, thus limiting comprehensive quantitative

423 assessment of perylene in recent sediments ${ }^{50}$. In contrast, the isotopic composition of perylene

424 is expected to be insensitive to conversion efficiency, and thus can serve as a robust tracer of

425 soil-derived terrestrial organic matter.

426

427 Acknowledgement

428 The authors thank John King, Sean Sylva, Brad Hubeny, Peter Sauer, Jim Broda for their help

429 in sampling, Carl Johnson and Daniel Montluçon for their incessant help with analyses as well

430 as Mark Yunker for critical discussion on the perils of perylene. Professor Phil Meyers and two

431 anonymous reviewers provided comments that improved the quality of the manuscript. U.M.H.

432 acknowledges the Swiss National Science Foundation for his postdoctoral fellowship and T.I.E.

433 and K.A.H. the NSF for research grants CHE-0089172 and OCE-9708478.

434

435 Supporting Information. Provides details on the preparative chromatographic isolation of

436 PAHs for compound-specific isotope analysis, the concept of two modes of terrigenous organic

437 matter export from land to oceans, the impact of the nuclear weapon testing on the atmospheric

438 and marine ${ }^{14} \mathrm{C}$ partitioning over time and results for grain size analyses, respectively.

439

$440 \quad$ Literature

441 (1) Orr, W. L.; Grady, J. R. Perylene in Basin Sediments off Southern California. Geochim.

442 Cosmochim. Acta 1967, 31, 1201-1209. https://doi.org/10.1016/S0016-7037(67)80058-

4439.

444 (2) Aizenshtat, Z. Perylene and Its Geochemical Significance. Geochim. Cosmochim. Acta 
1973, 37, 559-567. https://doi.org/10.1016/0016-7037(73)90218-4.

446 (3) Silliman, J. E.; Meyers, P. A.; Ostrom, P. H.; Ostrom, N. E.; Eadie, B. J. Insights into the Origin of Perylene from Isotopic Analyses of Sediments from Saanich Inlet, British Columbia. Org. Geochem. 2000, 31 (11), 1133-1142. https://doi.org/10.1016/S01466380(00)00120-0.

(4) Zhang, X.; Xu, Y.; Ruan, J.; Ding, S.; Huang, X. Origin, Distribution and Environmental Significance of Perylene in Okinawa Trough since Last Glaciation Maximum. Org. Geochem. 2014, 76, 288-294. https://doi.org/10.1016/j.orggeochem.2014.09.008.

(5) Venkatesan, M. I. Occurence and Possible Sources of Perylene in Marine Sediments-a Review *. Mar. Chem. 1988, 25 (2845), 1-27. https://doi.org/10.1016/03044203(88)90011-4.

(6) Meyers, P. A.; Ishiwatari, R. Lacustrine Organic Geochemistry-an Overview of Indicators of Organic Matter Sources and Diagenesis in Lake Sediments. Org. Geochem. 1993, 20 (7), 867-900. https://doi.org/10.1016/0146-6380(93)90100-P.

(7) Itoh, N.; Tamamura, S.; Kumagai, M. Distributions of Polycyclic Aromatic Hydrocarbons in a Sediment Core from the North Basin of Lake Biwa, Japan. Org. Geochem. 2010, 41 (8), 845-852. https://doi.org/10.1016/j.orggeochem.2010.04.002.

(8) Gschwend, P. M.; Hites, R. A. Fluxes of Polycyclic Aromatic Hydrocarbons to Marine 463 and Lacustrine Sediments in the Northeastern United States. Geochim. Cosmochim. Acta 1981, 45 (12), 2359-2367. https://doi.org/10.1016/0016-7037(81)90089-2.

(9) Wilcke, W.; Krauss, M.; Amelung, W. Carbon Isotope Signature of Polycyclic Aromatic Hydrocarbons (PAHs): Evidence for Different Sources in Tropical and Temperate Environments? Environ. Sci. Technol. 2002, 36 (16), 3530-3535. https://doi.org/10.1021/es020032h. 
(10) Gocht, T.; Barth, J. A. C.; Epp, M.; Jochmann, M.; Blessing, M.; Schmidt, T. C.; Grathwohl, P. Indications for Pedogenic Formation of Perylene in a Terrestrial Soil Profile: Depth Distribution and First Results from Stable Carbon Isotope Ratios. Appl. Geochemistry 2007, 22 (12), 2652-2663. https://doi.org/10.1016/j.apgeochem.2007.06.004.

(11) Schnurmann, R.; Maddams, W. F.; Barlow, M. C. Spectrophotometric Identification of Polynuclear Aromatic Components In High Boiling Petroleum Fractions. Anal. Chem. 1953, 25 (7), 1010-1013. https://doi.org/10.1021/ac60079a003.

(12) Wise, S. A.; Poster, D. L.; Leigh, S. D.; Rimmer, C. A.; Mössner, S.; Schubert, P.; Sander, L. C.; Schantz, M. M. Polycyclic Aromatic Hydrocarbons (PAHs) in a Coal Tar Standard Reference Material-SRM 1597a Updated. Anal. Bioanal. Chem. 2010, 398 (2), 717-728. https://doi.org/10.1007/s00216-010-4008-X.

(13) Simoneit, B. R. T.; Rogge, W. F.; Lang, Q.; Jaffé, R. Molecular Characterization of Smoke from Campfire Burning of Pine Wood (Pinus Elliottii). Chemosph. - Glob. Chang. Sci. 2000, 2 (1), 107-122. https://doi.org/10.1016/S1465-9972(99)00048-3.

(14) Wang, Z.; Fingas, M.; Shu, Y. Y.; Sigouin, L.; Landriault, M.; Lambert, P.; Turpin, R.; Campagna, P.; Mullin, J. Quantitative Characterization of PAHs in Burn Residue and Soot Samples and Differentiation of Pyrogenic PAH1 from Petrogenic PAHs - The 1994 Mobile Burn Study. Environ. Sci. Technol. 1999, 33 (18), 3100-3109. https://doi.org/10.1021/es990031y.

(15) Lima, A. L.; Eglinton, T. I.; Reddy, C. M. High-Resolution Record of Pyrogenic Polycyclic Aromatic Hydrocarbon Deposition during the 20th Century. Environ. Sci. Technol. 2003, 37 (1), 53-61. https://doi.org/10.1021/es025895p.

(16) Silliman, J. E.; Meyers, P. A.; Eadie, B. J.; Val Klump, J. A Hypothesis for the Origin of 
Perylene Based on Its Low Abundance in Sediments of Green Bay, Wisconsin. Chem. Geol. 2001, 177 (3-4), 309-322. https://doi.org/10.1016/S0009-2541(00)00415-0.

(17) Wakeham, S. G.; Canuel, E. A. Biogenic Polycyclic Aromatic Hydrocarbons in Sediments of the San Joaquin River in California (USA), and Current Paradigms on Their Formation. Environ. Sci. Pollut. Res. 2016, 23 (11), 10426-10442. https://doi.org/10.1007/s11356-015-5402-x.

(18) Fan, C. W.; Shiue, J.; Wu, C. Y.; Wu, C. Y. Perylene Dominance in Sediments from a Subtropical High Mountain Lake. Org. Geochem. 2011, 42 (1), 116-119. https://doi.org/10.1016/j.orggeochem.2010.10.008.

(19) Hites, R. A.; Laflamme, R. E.; Windsor, J. G.; Farrington, J. W.; Deuser, W. G. Polycyclic Aromatic Hydrocarbons in an Anoxic Sediment Core from the Pettaquamscutt River (Rhode Island, U.S.A.). Geochim. Cosmochim. Acta 1980, 44 (6), 873-878. https://doi.org/10.1016/0016-7037(80)90267-7.

(20) Gschwend, P. M.; Chen, P. H.; Hites, R. A. On the Formation of Perylene in Recent Sediments: Kinetic Models. Geochim. Cosmochim. Acta 1983, 47 (12), 2115-2119. https://doi.org/10.1016/0016-7037(83)90036-4.

(21) Wakeham, S. G. Synchronous Fluorescence Spectroscopy and Its Application to Indigenous and Petroleum-Derived Hydrocarbons in Lacustrine Sediments. Environ. Sci. Technol. 1977, 11 (3), 272-276. https://doi.org/10.1021/es60126a012.

(22) Grice, K.; Lu, H.; Atahan, P.; Asif, M.; Hallmann, C.; Greenwood, P.; Maslen, E.; Tulipani, S.; Williford, K.; Dodson, J. New Insights into the Origin of Perylene in Geological Samples. Geochim. Cosmochim. Acta 2009, 73 (21), 6531-6543. https://doi.org/10.1016/j.gca.2009.07.029. 
Originating from Cenococcum Geophilum in Its Catchment Area. Geochim. Cosmochim. Acta 2012, 95, 241-251. https://doi.org/10.1016/j.gca.2012.07.037.

519

520

521

522

523

524

525

526

527

528

529

530

531

532

533

534

535

536

537

538

539

540
(24)

Louda, J. W.; Baker, E. W. Perylene Occurrence, Alkylation and Possible Sources in Deep-Ocean Sediments. Geochim. Cosmochim. Acta 1984, 48 (5), 1043-1058. https://doi.org/10.1016/0016-7037(84)90195-9.

(25) Jautzy, J. J.; Ahad, J. M. E.; Hall, R. I.; Wiklund, J. A.; Wolfe, B. B.; Gobeil, C.; Savard, M. M. Source Apportionment of Background PAHs in the Peace-Athabasca Delta (Alberta, Canada) Using Molecular Level Radiocarbon Analysis. Environ. Sci. Technol. 2015, 49 (15), 9056-9063. https://doi.org/10.1021/acs.est.5b01490.

(26) Obase, K.; Douhan, G. W.; Matsuda, Y.; Smith, M. E. Progress and Challenges in Understanding the Biology, Diversity, and Biogeography of Cenococcum Geophilum. In Biogeography of Mycorrhizal Symbiosis; Tedersoo, L., Ed.; Springer International Publishing, 2017; Vol. Ecological, pp 299-318. https://doi.org/10.1007/978-3-319$56363-3$

(27) Suzuki, N.; Yessalina, S.; Kikuchi, T. Probable Fungal Origin of Perylene in Late Cretaceous to Paleogene Terrestrial Sedimentary Rocks of Northeastern Japan as Indicated from Stable Carbon Isotopes. Org. Geochem. 2010, 41 (3), 234-241. https://doi.org/10.1016/j.orggeochem.2009.11.010.

(28) Strullu-Derrien, C.; Selosse, M. A.; Kenrick, P.; Martin, F. M. The Origin and Evolution of Mycorrhizal Symbioses: From Palaeomycology to Phylogenomics. New Phytol. 2018, 220 (4), 1012-1030. https://doi.org/10.1111/nph.15076.

(29) Allport, D. C.; Bu'Lock, J. D. Biosynthetic Pathways in Daldina Concentrica. J. Chem. Soc. 1960, No. 654-662. https://doi.org/10.1039/JR9600000654.

(30) Wu, H.; Lao, X. F.; Wang, Q. W.; Ren-Rong, L.; Shen, C.; Zhang, F.; Liu, M.; Jia, L. 
The Shiraiachromes: Novel Fungal Perylenequinone Pigments from Shiraia Bambusicola. J. Nat. Prod. 1989, 52 (5), 948-951. https://doi.org/10.1021/np50065a006.

(31) Daub, M. E.; Herrero, S.; Chung, K. R. Photoactivated Perylenequinone Toxins in Fungal Pathogenesis of Plants. FEMS Microbiol. Lett. 2005, 252 (2), 197-206. https://doi.org/10.1016/j.femsle.2005.08.033.

(32) Marynowski, L.; Smolarek, J.; Bechtel, A.; Philippe, M.; Kurkiewicz, S.; Simoneit, B. R. T. Perylene as an Indicator of Conifer Fossil Wood Degradation by Wood-Degrading Fungi. Org. Geochem. 2013, 59, 143-151. https://doi.org/10.1016/j.orggeochem.2013.04.006.

(33) Kaden, D. A.; Hites, R. A.; Thilly, W. G. Mutagenicity of Soot and Associated Polycyclic Aromatic Hydrocarbons to Salmonella Typhimurium. Cancer Res. 1979, 39 (10), 4152-4159. https://doi.org/10.1109/ICDM.2018.00085.

(34) United States Environmental Protection Agency. Provisional Peer Reviewed Toxicity Values for Perylene (CASRN 198-55-0); Cincinnati, 2006.

(35) Hanke, U. M.; Reddy, C. M.; Braun, A. L. L.; Coppola, A. I.; Haghipour, N.; McIntyre, C. P.; Wacker, L.; Xu, L.; McNichol, A. P.; Abiven, S.; Schmidt, M. W. I.; Eglinton, T. I. What on Earth Have We Been Burning? Deciphering Sedimentary Records of Pyrogenic Carbon. Environ. Sci. Technol. 2017, 51 (21), 12972-12980. https://doi.org/10.1021/acs.est.7b03243.

(36) Hubeny, J. B.; King, J. W.; Cantwell, M. Anthropogenic Influences on Estuarine Sedimentation and Ecology: Examples from the Varved Sediments of the Pettaquamscutt River Estuary, Rhode Island. J. Paleolimnol. 2009, 41, 297-314. https://doi.org/10.1007/s10933-008-9226-2.

(37) Hanke, U. M.; Eglinton, T. I.; Braun, A. L. L.; Reddy, C. M.; Wiedemeier, D. B.; 
Schmidt, M. W. I. Decoupled Sedimentary Records of Combustion: Causes and Implications. Geophys. Res. Lett. 2016, 43 (10), 5098-5108. https://doi.org/10.1002/2016GL069253.

(38) Fitzgerald, W. F.; Engstrom, D. R.; Hammerschmidt, C. R.; Lamborg, C. H.; Balcom, P. H.; Lima-Braun, A. L.; Bothner, M. H.; Reddy, C. M. Global and Local Sources of Mercury Deposition in Coastal New England Reconstructed from a Multiproxy, HighResolution, Estuarine Sediment Record. Environ. Sci. Technol. 2018, 52 (14), 7614 7620. https://doi.org/10.1021/acs.est.7b06122.

(39) Lima, A. L.; Hubeny, J. B.; Reddy, C. M.; King, J. W.; Hughen, K. A.; Eglinton, T. I. High-Resolution Historical Records from Pettaquamscutt River Basin Sediments: 1. $210 \mathrm{~Pb}$ and Varve Chronologies Validate Record of 137Cs Released by the Chernobyl Accident. Geochim. Cosmochim. Acta 2005, 69 (7), 1803-1812. https://doi.org/10.1016/j.gca.2004.10.009.

(40) Drenzek, N. J.; Montluçon, D. B.; Yunker, M. B.; Macdonald, R. W.; Eglinton, T. I. Constraints on the Origin of Sedimentary Organic Carbon in the Beaufort Sea from Coupled Molecular13C And14C Measurements. Mar. Chem. 2007, 103 (1-2), 146-162. https://doi.org/10.1016/j.marchem.2006.06.017.

(41) Eglinton, T. I.; Aluwihare, L. I.; Bauer, J. E.; Druffel, E. R. M.; McNichol, A. P. Gas Chromatographic Isolation of Individual Compounds from Complex Matrices for Radiocarbon Dating. Anal. Chem. 1996, 68, 904-912. https://doi.org/10.1021/ac9508513.

(42) Reimer, P. J.; Brown, T. A.; Reimer, R. W. Discussion: Reporting and Calibration of Post-Bomb 14C Data. Radiocarbon 2004, 46 (3), 1299-1304. https://doi.org/10.2458/azu_js_rc.46.4183. 
(43) Reimer, P. J.; Bard, E.; Bayliss, A.; Beck, J. W.; Blackswell, P. G.; Ramsey, C. B.; Buck, C. E.; Cheng, H.; Edwards, R. L.; Friedrich, M.; Grootes, P. M.; Guilderson, T. P.; Haflidason, H.; Hajdas, I.; Hatté, C.; Heaton, T. J.; Hoffmann, D. L.; Hogg, A. G.; Hughen, K. A.; Kaiser, K. F.; Kromer, B.; Manning, S. W.; Niu, M.; Reimer, R. W.; Richards, D. A.; Scott, E. M.; Southon, J. R.; Staff, R. A.; Turney, C. S. M.; van der Pflicht, J. Intcal13 and Marine13 Radiocarbon Age Calibration Curves 0-50,000 Years Cal BP. Radiocarbon 2013, 55 (4), 1869-1887. https://doi.org/10.2458/azu_js_rc.55.16947.

(44) Blattmann, T. M.; Letsch, D.; Eglinton, T. I. On the Geological and Scientific Legacy of Petrogenic Organic Carbon. Am. J. Sci. 2018, 318 (8), 861-881. https://doi.org/10.2475/08.2018.02.

(45) Gaines, A. G. Papers on the Geomorphology, Hydrography and Geochemistry of the Pettaquamscutt River Estuary. PhD Dissertation, University of Rhode Island, 1975.

(46) Meyers, P. A. Preservation of Elemental and Isotopic Source Identification of Sedimentary Organic Matter. Chem. Geol. 1994, 114 (3-4), 289-302. https://doi.org/10.1016/0009-2541(94)90059-0.

(47) Levin, I.; Kromer, B.; Hammer, S. Atmospheric D14CO2 Trend in Western European Background Air from 2000 to 2012. Tellus B 2013, 65 (20092), 1-7. https://doi.org/10.3402/tellusb.v65i0.20092.

(48) Meyers, P. A. Organic Geochemical Proxies of Paleoceanographic, Paleolimnologic, and Paleoclimatic Processes. Org. Geochem. 1997, 27 (5/6), 213-250. https://doi.org/10.1016/S0146-6380(97)00049-1.

(49) Tan, Y. L.; Heit, M. Biogenic and Abiogenic Polynuclear Aromatic Hydrocarbons in Sediments from Two Remote Adirondack Lakes. Geochim. Cosmochim. Acta 1981, 45 
614 (50) Slater, G. F.; Benson, A. A.; Marvin, C.; Muir, D. PAH Fluxes to Siskiwit Revisited: Trends in Fluxes and Sources of Pyrogenic PAH and Perylene Constrained via Radiocarbon Analysis. Environ. Sci. Technol. 2013, 47 (10), 5066-5073. https://doi.org/10.1021/es400272z.

(51) O’Leary, M. Carbon Isotopes in Photosynthesis. Bioscience 1988, 38 (5), 328-336. https://doi.org/10.2307/1310735.

620

621

622

623

624

625

626

627

628

629

630

631

632

633

634

635

636

(52) Lehmann, J.; Kleber, M. The Contenious Nature of Soil Organic Matter. Nature 2015, 528, 60-68. https://doi.org/10.1038/nature16069.

(53) Berhe, A. A.; Barnes, R. T.; Six, J.; Marín-Spiotta, E. Role of Soil Erosion in Biogeochemical Cycling of Essential Elements: Carbon, Nitrogen, and Phosphorus. Annu. Rev. Earth Planet. Sci. 2018, 46 (1), 521-548. https://doi.org/10.1146/annurevearth-082517-010018.

(54) Douglas, P. M. J.; Pagani, M.; Eglinton, T. I.; Brenner, M.; Hodell, D. A.; Curtis, J. H.; Ma, K. F.; Breckenridge, A. Pre-Aged Plant Waxes in Tropical Lake Sediments and Their Influence on the Chronology of Molecular Paleoclimate Proxy Records. Geochim. Cosmochim. Acta 2014, 141, 346-364. https://doi.org/10.1016/j.gca.2014.06.030.

(55) French, K. L.; Hein, C. J.; Haghipour, N.; Wacker, L.; Kudrass, H. R.; Eglinton, T. I.; Galy, V. Millennial Soil Retention of Terrestrial Organic Matter Deposited in the Bengal Fan. Sci. Rep. 2018, 8 (1), 1-8. https://doi.org/10.1038/s41598-018-30091-8.

(56) Vonk, J. E.; Drenzek, N. J.; Hughen, K. A.; Stanley, R. H. R.; McIntyre, C.; Montluçon, D. B.; Giosan, L.; Southon, J. R.; Santos, G. M.; Druffel, E. R. M.; Andersson, A. A.; Sköld, M.; Eglinton, T. I. Temporal Deconvolution of Vascular Plant-Derived Fatty Acids Exported from Terrestrial Watersheds. Geochim. Cosmochim. Acta 2019, 244, 
502-521. https://doi.org/10.1016/j.gca.2018.09.034.

638 (57) Coppola, A. I.; Wiedemeier, D. B.; Galy, V.; Haghipour, N.; Hanke, U. M.; Nascimento,

639

640

641

642

643

644

645

646

647

648

649

650

651

652

653

654

655

656

657

658

659

660

G. S.; Usman, M.; Blattmann, T. M.; Reisser, M.; Freymond, C. V.; Zhao, M.; Voss, B.;

Wacker, L.; Schefuß, E.; Peucker-Ehrenbrink, B.; Abiven, S.; Schmidt, M. W. I.;

Eglinton, T. I. Global-Scale Evidence for the Refractory Nature of Riverine Black

Carbon. Nat. Geosci. 2018, 11 (8), 584-588. https://doi.org/10.1038/s41561-018-0159-8.

(58) Burdige, D. J. Burial of Terrestrial Organic Matter in Marine Sediments: A Re-

Assessment. Global Biogeochem. Cycles 2005, 19 (4), 1-7.

https://doi.org/10.1029/2004gb002368.

(59) Oros, D. R.; Simoneit, B. R. T. Identification and Emission Factors of Molecular Tracers in Organic Aerosols from Biomass Burning Part 1. Temperate Climate Conifers; 2001; Vol. 16. https://doi.org/10.1016/S0883-2927(01)00021-X.

(60) Venkatesan, M. I.; Kaplan, I. R. The Lipid Geochemistry of Antarctic Marine Sediments: Bransfield Strait. Mar. Chem. 1987, 21 (2844), 347-375. https://doi.org/10.1016/03044203(87)90056-9.

(61) Jiang, C.; Alexander, R.; Kagi, R. I.; Murray, A. P. Origin of Perylene in Ancient Sediments and Its Geological Significance. Org. Geochem. 2000, 31 (12), 1545-1559. https://doi.org/10.1016/S0146-6380(00)00074-7.

(62) Sánchez-Ramírez, S.; Wilson, A. W.; Ryberg, M. Overview of Phylogenetic Approaches to Mycorrhizal Biogeography, Diversity and Evolution. In Biogeography of Mycorrhizal Symbiosis; Tedersoo, L., Ed.; Springer International Publishing, 2017; Vol. 230, pp 138. https://doi.org/10.1007/978-3-319-56363-3.

(63) Blumer, M. Organic Pigments : Their Long-Term Fate. Science. 1965, 149 (3685), $722-$ 726. https://doi.org/10.1126/science.149.3685.722. 
661 (64) Fernandez, C. W.; Langley, J. A.; Chapman, S.; McCormack, M. L.; Koide, R. T. The 662 Decomposition of Ectomycorrhizal Fungal Necromass. Soil Biol. Biochem. 2016, 93, 38663 49. https://doi.org/10.1016/j.soilbio.2015.10.017.

664 (65) Bianchi, T. S.; Cui, X.; Blair, N. E.; Burdige, D. J.; Eglinton, T. I.; Galy, V. Centers of 665 Organic Carbon Burial and Oxidation at the Land-Ocean Interface. Org. Geochem. 2018, $666 \quad 115,138-155$. https://doi.org/10.1016/j.orggeochem.2017.09.008.

667 (66) Hedges, J. I.; Oades, J. M. Comparative Organic Geochemistries of Soils and Marine 668 Sediments. Org. Geochem. 1997, 27 (7-8), 319-361. https://doi.org/10.1016/s0146$669 \quad 6380(97) 00056-9$.

670 